\title{
Berlin Wild - and the Max Delbrück Center for Molecular Medicine (MDC) Berlin-Buch
}

\author{
Friedrich C. Luft $^{1}$
}

Published online: 4 May 2017

(C) Springer-Verlag Berlin Heidelberg 2017

With this title, one thinks of Berlin in the roaring 1920s, or perhaps in the late 1960s, during the Shah's visit and Benno Ohnesorg's tragic and hapless (Deutsche Demokratische Republik (DDR)-arranged) death. Not hardly - the date was 1943 - and Berlin was closely checked and not wild. When I came to Berlin in 1992, I had the good fortune to spend an evening with four internationally renowned geneticists. Karl Sperling invited me to attend a dinner that included Regine Witkowski, Arno Motulsky, and Friedrich Vogel. I am not a geneticist but had recently been recruited to initiate some human genetic studies on cardiovascular disease at the newly founded Max Delbrück Center for Molecular Medicine (MDC) in Berlin-Buch. As a matter of fact, Regine Witkowski later chauffeured me back to my room in BerlinBuch in her Wartburg.

The four geneticists explained to me that the forerunner of the MDC was a renowned center of novel genetics research. Motulsky suggested that I read a bit about Nikolai TimofejewRessowski and the history of the Kaiser Wilhelm Institute (KWI) for Brain Research [1]. Timofejew-Ressowski had been a 24-year-old graduate student, when the two politically left-leaning neuropathologists Oskar and Cécile Vogt came to Moscow in 1924 to inspect Lenin's brain. They found Timofejew-Ressowski's brain more interesting and recruited him to come to Berlin. Some of his research at the Institute for Experimental Biology in Moscow involved Drosophila melanogaster. In 1932, Hermann Joseph Muller moved to

Friedrich C. Luft

luft@ charite.de

Experimental and Clinical Research Center, a joint cooperation between the Charité Medical Faculty and the Max Delbrück Center for Molecular Medicine, Lindenbergerweg 80,

13125 Berlin, Germany
Berlin to work together with Timofejew-Ressowski, a trip intended as a limited sabbatical stretched into an 8-year, five-country journey. In Berlin, Muller met two physicists who would later be significant to the biology community, namely Niels Bohr and Max Delbrück. At the time, Max Delbrück was a struggling post-doc in the laboratory of Lise Meitner [2]. In 1935, Timofejew-Ressowski published his major work "Über die Natur der Genmutation und der Genstruktur" with Karl Zimmer and Max Delbrück [2, 3]. This paper was the beginning of molecular biology and eventually led to the naming of the MDC. The paper had substantial influence; another physicist, Erwin Schrödinger, was so fascinated by it that he lectured and compiled a booklet termed, "What is life" [2]. This booklet later influenced James Watson and a generation of young people.

"To understand the life of Timofejew-Ressowski, you must read Daniil Granin and his book, The Geneticist", Motulsky explained. I was able to obtain an East-German addition with a somewhat different title: Sie nannten ihn Ur (They called him Ur) [4]. Ur (Ger. Aueroxe, Bos primigenius) is an extinct form of oxen from which modern European domesticated cattle were derived (Fig. 1). The nickname was clearly an honor denoting the steadfast, stubborn integrity that marked the man's life. Motulsky also presented me a copy of the most recent edition of his own book, Human Genetics, co-authored by Friedrich Vogel [5]. Indeed, the book was very helpful to me and remains the only genetics text that I have ever owned. Motulsky also recommended that I read, Berlin Wild, by Elly Welt [6]. I found the book; our library had a copy that I was allowed to inspect for 2 weeks. The book was interesting and indeed was about the KWI during World War II, the adventures of Ur, the little wine makers living there both domestic and wild, and the KWI personnel, living and surviving the German madness of the time. Recently, 25 years later, I found a German translation in the office of the current MDC director 
Figure 1 Nikolai TimofejewRessowski (A). They called him $U r(\mathbf{B})$
A

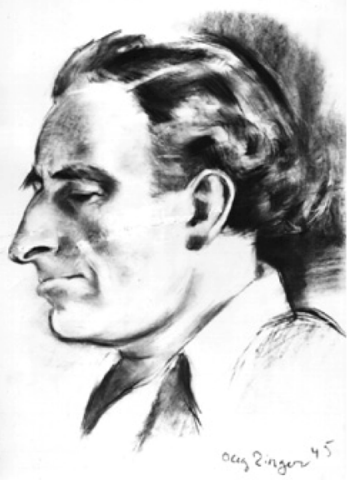

B

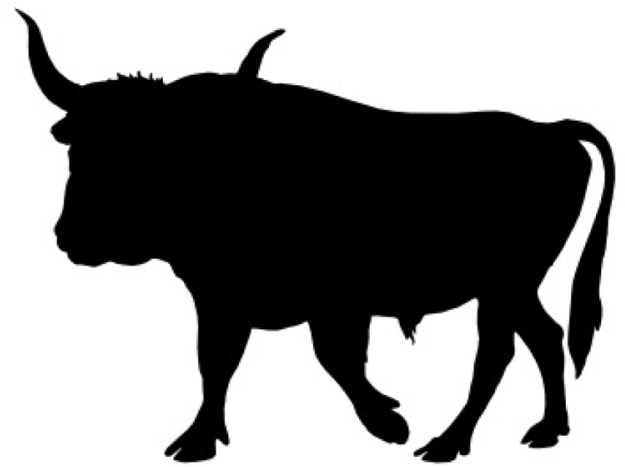

(Berliner Labyrinth). I borrowed the volume and revisited Berlin Wild.

The story is the product of the University of Iowa's Writer's Workshop, a 2-year residency program, which culminates in the submission of a creative thesis (a novel, a collection of stories, or a book of poetry) and the awarding of a Master of Fine Arts degree. I assume Elly Welt is a graduate. In any event, she was there and studied with the notable author, John Cheever. Cheever's influence in Elly Welt's book may be apparent to some of you who know his work.

In the book, we first meet the physician, Joseph Bernhardt, in 1967, as he is about to intubate a patient at the University of Iowa Hospital. He is a first-class anesthesiologist, McGill graduate, and new faculty member. Those of you who know Iowa City as I do (I am adjunct faculty at the institution), will recognize the nice University town representing the "Heart Land" of America. Furthermore, those of you who know clinical medicine will find that the medical portrayal in the book is invariably excellent. But Joseph's life is not in order and we are soon to find out why, as we shift to 24 years earlier.

We next encounter Joseph Bernhardt as the 16-year-old son of a non-Jewish attorney father and a Jewish physician mother, who both consider themselves to be German (which they are) and both can trace their ancestry to German soil for 500 years. Joseph attends the oldest public high school in Berlin (Gymnasium), the Collège Français, founded by Huguenots in 1685. The Grand Elector, Friedrich Wilhelm, invited the persecuted Huguenots to Prussia before Prussia became a kingdom. Of course in 1943, no half-Jewish students are allowed even at the Collège Français and Joseph must leave the school. He finds refuge in the fifth story of the KWI in Berlin-Buch, an environment surrounding him with brains in formalin-filled jars, some of which belonged to killed Luftwaffe pilots, and others of still more nefarious origin. The KWI consists of three research divisions, one of which is dedicated to researching radiation-induced genetic mutations, mostly in Drosophila. That division enjoyed relative independence from the rest of the KWI and employed numerous foreign scientific personnel. Joseph owes this refuge to his friend and slightly older Collège Français classmate, Mitzka, who is the son of the chief geneticist, Timofejew-Ressowski, at the KWI.

What makes the story more than just another book about persons with Jewish parentage surviving the horrors of Nazi Germany is the uncanny precision of Welt's portrayal of BerlinBuch and the persons working at the KWI, although the names are changed in her historical novel. Even the S-Bahn stations to Buch, the $2 \mathrm{~km}$ to the institute, the description of the buildings, and the KWI organizational structure, are accurate. Most compelling is the accurate description of Timofejew-Ressowski and his wife Helena, an important scientist in her own right. They had a teenaged son, named Dimitri, who conspired with other youngsters against the Nazis. Dimitri was captured, incarcerated, and finally executed at the Matthausen concentration camp very close before the war's end. Timofejew-Ressowski gave refuge to numerous foreigners during the war and with great courage and finesse; he managed to save most of them. His team of dedicated scientists and technical staff were helpful in that regard and the separation from the Luftwaffe-managed side of the KWI and its other activities must surely have been helpful.

Joseph learns Drosophila genetics. Drosophila is the "dew lover". Wildtype fruit flies have brick red eyes, are yellow-brown in color, and have transverse black rings across their abdomen. Indeed, the flies are captured on the grounds of the institute and were named by Timofejew-Ressowski as "Berlin Wild" (wild-type), hence Welt's title with no little irony. Drosophila feed on the microorganisms (yeast) that decompose the fruit, as well as on the sugar of the fruit itself. The yeasts engage in fermentation, making alcohol and thus, the designation of Drosophila as "little wine makers", as they move the yeasts, thereby spreading pleasure. The Drosophila cultures are maintained on polenta (a cornmeal dish) and molasses, which the KWI has in unlimited quantities. This state-of-affairs enables the institute members to produce alcohol in similarly unlimited amounts; vodka assists science and the resistance. 
Joseph is a math and electronics whiz, which comes in handy for keeping the radios clandestinely tuned to the BBC and also for keeping the wheezing linear accelerator running. This temperamental instrument is necessary for X-ray production required for Drosophila research, as well as for the treatment of the Hodgkin's disease, afflicting the token SS man guarding the KWI; "Better the known ax in the house, rather than the unknown firemen with axes on the roof", comments the Chief dryly.

Sooner or later in the story, as in real-life, the noose tightened for Jews in Berlin. Joseph's mother, aunt, uncle, and others are deported "eastward," and no amounts of iron crosses earned in World War I help to ward off the terror. Joseph too is picked up by the authorities and packed off to work for IG-Farben, and then to another labor camp. However, the KWI physics professor has sent a protective umbrella through his connections. Joseph escapes during the last days of April chaos and steers his way back to BerlinBuch and the KWI when the Russians come.

How close is reality to the novel? The answer is "acceptable." Indeed, the Nazis classified Timofejew-Ressowski's work as "highly important for the war effort", surely not because of the flies, but probably because of the linear accelerator. No evidence exists that the Germans had a nuclear weapons program of any consequence, certainly not an organized effective program; however, radiation biology was deemed highly relevant for the war effort. In September 1945, Timofejew-Ressowski was arrested by the Russians and removed to the Gulag archipelago. Karl Zimmer, the radiation physicist, and others were similarly deported into the Soviet Union to Sugal in the Urals until 1955. The subsequent adventures were not all negative and can be reviewed elsewhere [4]. Timofejew-Ressowski died in 1981 in Obninsk. Helena, his wife, preceded him in 1973. A minor planet, 3238 Timresovia discovered by Soviet astronomer Nikolai Stepanovich Chernykh in 1975, is named after him. We in Berlin-Buch would have preferred a major planet.

Timofejew-Ressowski could not return to Russia in 1933; even though he was well aware of the Nazi's aims and intentions. However, genetics in the Soviet Union had taken on political dimensions and science was subservient to the state. Timofejew-Ressowski's scientific mentors in the Soviet Union warned against his return and pleaded with him accordingly. Indeed, after he was brought back to the Soviet Union, he could not interact with others scientifically until after Stalin was dead.

Joseph Bernhardt's adventures in this microcosm within a macrocosmic of madness are marked with pathos. We return to Iowa City. Even here, the geography is completely correct to all of us who know Iowa City. Joseph's intentions, with benzodiazepines and succinyl choline to end his own life are superseded by a catharsis. In Joseph's moment of intolerable pain, the very idea to say the Kaddish for all of the victims in the story provides deliverance. Joseph Bernhardt's sole connection to the Kaddish (he had been raised Christian protestant) is related solely to a piece of paper forced upon him by his uncle prior to deportation. Interesting was the exchange between the most eclectic and harried (by other duties) young Rabbi over the telephone regarding a dying patient: "Why do not you say it?" - "But I am not Jewish!" - "But how do you know?" I was fascinated by this novel, 20 years ago and again recently. It is a Berlin-Buch story and deserves to be retold.

Respectfully,

Friedrich C. Luft

\section{Post-script}

I am taking the liberty of writing a post-script to Friedrich (Fred) Luft's comment on an important episode in the history of science in Berlin-Buch, because this year 2017 not only marks the $25^{\text {th }}$ anniversary of the MDC but also the $75^{\text {th }}$ anniversary of Fred Luft. History meets history.

Ever since the traditional old German journal "Klinische Wochenschrift," founded as the "Berliner Klinische Wochenschrift" in 1864, experienced its latest transformation into the "Journal of Molecular Medicine" in 1995 with the editorial office in Berlin-Buch [7], the Journal is an archive of the development of science and history and Fred Luft has been a member of the editorial board. In this role, he has enriched almost every issue for more than 20 years with his sharp insights and comments, fantastic editorials, clinical, and also historical views. To get a sense of Fred's personality, one needs only a look at the titles of some of his pieces: "Could licorice lick inflammasomes?" "NFAT5 moves to Fat City," "Tripping out on TRP4," "GABA the Hutt"... the list goes on and on, forming a trail of publications as diverse as it is amazingly long. The editorial in this issue on the book "Berlin Wild" by Elly Welt is not Fred's first comment on the rich history of Berlin-Buch.

Fred Luft is the son of one of the famous clique of scientists surrounding Hubertus Strughold, who in the 1930s and 40s was involved in German programs on high altitude physiology and aviation medicine. After World War II, the Luft family moved to the USA with much of a team to work with General Harry Armstrong to enable pilots flying above $65,000 \mathrm{ft}$. close to the boilingpoint of blood. Fred was raised in the USA and studied medicine. He came back to Germany in the late 1980s. In 1992, I asked him to become the head of the Nephrology and Hypertension Clinic (Franz-Volhard) at the CharitéUniversitätsmedizin Berlin. An additional responsibility was to run the clinical research programs at the closely affiliated MDC, newly founded after German reunification. Berlin mirrors the development of biomedical research and German history over the last 100 years - especially the Campus in BerlinBuch, home to the largest hospital campus of 3,000 beds, the 
Kaiser Wilhelm Institute of Brain Research with its history of colorful figures and the Central Institutes for Biomedical Research of the East German Academy of Sciences. Oskar and Cécile Vogt established a research institute that soon welcomed Nikolai Timofejew-Ressowski and Max Delbrück. Fred Luft continues this tradition of colorful personalities as one of the few scientists who has not only made great contributions to cardiovascular and genetic research, but also at the same time preserved and transmitted a vivid sense of history of science and its historical context.

Fred Luft has made his own mark on this tradition. In his early days in Buch, a member of his group uncovered a forgotten article related to the genetics of hypertension, a theme that continues to haunt nephrologists. Written in the early 1970s by a Turkish physician named Nihat Bilganturan, the paper described the only known case of essential hypertension to follow a Mendelian pattern of inheritance. Fred contacted Nihat Bilginturan and then packed up his team, which included two young physicians of Turkish-German heritage, and headed off to pursue the case. His reasoning: whatever gene was responsible for the disease might provide insights into the form of essential hypertension that has increasingly ravaged populations around the world. Although he had no way of knowing it at the time, this case would occupy his laboratory at the MDC for more than 20 years-mostly because it resisted a solution. Those first 20 years of MDC history witnessed amazing developments in the life sciences, and Fred Luft continually adapted to new concepts and technologies in pursuit of an answer to the causes of this novel Mendelian form of hypertension. Finally in 2015, with a paper in Nature Genetics, he provided a solution and proved that an old dog can indeed, teach youngsters new tricks [8]. At the mature age of 75, he still has his teeth sunk into the story.

An entire book called The Case of the Short-fingered Musketeer has been written about Fred Luft and this project, and anyone wishing to get to know the extraordinary scientist Fred Luft through an intimate, novelistic portrait should read it. A copy can be ordered through this journal's editorial office - see the note below. So, it is more than fitting that Fred Luft's commentary in this issue of the Journal of Molecular Medicine coincides with his birthday. Here, he recalls the historical background of genetic research in Berlin-Buch in the context of German history in the 1930s and 1940s. Fred himself has made major contributions to genetic research in Berlin-Buch and contributed to history and we hope he will appreciate this meager post-script, in honor of his $75^{\text {th }}$ birthday.
Fred is a clinician who aspires to science. He has contributed to cardiovascular research in many ways, he is an excellent clinician, a great teacher, and a collector of students and friends around the world. I am honored to be one of them. We wish him all the best for the future and we are expecting more of those commentaries in the Journal of Molecular Medicine.

Detlev Ganten

Editor in Chief

Journal of Molecular Medicine

Berlin-Buch

\section{Note:}

"The Case of the short-fingered musketeer," by Russ Hodge, copyright 2013. Published by the Max Delbrück Center for Molecular Medicine of the Helmholtz Association. 310 pages, full-color, ca. 100 photos and illustrations.

This is the story of a modern biomedical adventure: the 20year quest by Fred Luft and his laboratory to find the causes of hereditary hypertension affecting a Turkish family living on the coast of the Black Sea. The lavishly illustrated book provides a unique look into today's biomedical research -recounting the human story of a group of scientists and the family they are studying, and tracing the ongoing, sweeping developments in modern genetic science that are affecting all of our lives.

To place an order for a free copy, please send an e-mail to jmmoff@mdc-berlin.de. The editors will send you details about shipping.

\section{References}

1. Bielka H (2002) Geschichte der medizinisch-biologischen Institute Berlin-Buch. Springer, Berlin

2. Luft FC (2007) Who was Max Delbrück? J Mol Med 85:207-211

3. Timofeeff-Ressovsky NW (1937) Experimentelle Mutationsforschung in der Vererbungslehre. Beeinflussung der Erbanlagen durch Strahlung und andere Faktoren.Dresden, Leipzig: Theodor Steinkopff Verlag

4. Granin D (1988) Sie nannten ihn Ur. Roman eines Lebens. Aus dem Russischen von Erich Ahrndt. Verlag Volk und Welt, Berlin. ISBN 3353-00397-5

5. Vogel F, Motulsky A (1982) Human genetics - problems and approaches. Springer, Berlin

6. Welt E (1986) German translation: Berliner labyrinth (1987) translated by guy Montag. Benziger. Viking Press, Berlin Wild

7. Ganten D (1995) The Journal of Molecular Medicine: tradition, continuity, and renaissance. J Mol Med 73:1-3

8. Maass PG, Aydin A, Luft FC, Schächterle C, Weise A, Stricker S, Lindschau C, Vaegler M, Qadri F, Toka HR et al (2015) PDE3A mutations cause autosomal dominant hypertension with brachydactyly. Nat Genet. Jun;47:647-53. doi:10.1038/ng.3302 